\title{
INTRAVENOUS METHYLPREDNISOLONE PULSE THERAPY IN PAEDIATRIC PATIENTS WITH TYPICAL HAEMOLYTIC UREMIC SYNDROME AND NEUROLOGICAL COMPLICATIONS
} \author{
CATALIN GABRIEL CIRSTOVEANU ${ }^{1,2 \#}$ \\ 1 "Carol Davila" University of Medicine and Pharmacy, Bucharest, Romania \\ 2 "Maria Sklodowska Curie” Children's Emergency Hospital, Bucharest, Romania \\ *corresponding author: bcamelia@gmail.com \\ ${ }^{\#}$ Authors with equal contribution.
}

MARCELA DANIELA IONESCU ${ }^{1,2 \#, ~ M I H A E L A ~ B A L G R A D E A N ~}{ }^{1,2}$, CRISTINA FILIP ${ }^{2}$, LOREDANA IONELA POPA $^{1,2}$, CARMEN PAVELESCU ${ }^{2 \#}$, ELENA CAMELIA BERGHEA ${ }^{1,2 *}$,

\begin{abstract}
Typical haemolytic uremic syndrome (HUS), caused by the enterohaemorrhagic Escherichia coli (EHEC), is thrombotic microangiopathy in which neurological complications often lead to serious long-term sequelae, being also responsible for the majority of deaths in paediatric population. We performed a retrospective study of 89 patients with HUS, at the Nephrology Department of "Maria Sklodowska Curie" Children's Emergency Hospital, Bucharest, Romania. The aim of this study was to determine whether methylprednisolone (mPSL) intravenous pulse therapy could be of clinical benefits in patients diagnosed with HUS and neurological complications. Based on the severity of the cases, the patients were grouped into two categories: patients with mild-HUS (serum creatinine $<1.5 \mathrm{mg} / \mathrm{dL}$ ), were compared to patients with severe-HUS (creatinine serum $>1.5$ and neurological complications). Administration of mPSL pulse therapy resulted in significant reductions of neurological complications, and a positive outcome was noted in 15 of 16 patients with severe-HUS. The mPSL therapy did not cause significant adverse effects. Receiver operating characteristic (ROC) curve was constructed to assess the predictive performance on laboratory parameters, in group with severe-HUS, after mPSL administration. The product of haemoglobin showed an AUC (area under the curve) of 0.8105 , and serum creatinine was a predictor of severe vs. mild HUS. Serum creatinine showed a good prediction for mPSL administration in severe-HUS group (AUC 0.9453, 95\% CI, 0.8577 - 1.00). Our data suggest that mPSL pulse therapy in children with neurological complications during the acute phase of HUS was associated with significant improvement of neurological, haematological, and renal function.
\end{abstract}

\section{Rezumat}

Sindromul hemolitic uremic tipic (SHU), cauzat de Escherichia coli enterohemoragică (EHEC), este o microangiopatie trombotică în care complicațiile neurologice duc adesea la sechele grave pe termen lung, fiind responsabile de majoritatea deceselor în rândul populației pediatrice. Am efectuat un studiu retrospectiv pe 89 de pacienți cu SHU, în cadrul Secției de Nefrologie a Spitalului de Urgență pentru Copii „Maria Sklodowska Curie”, București, România. Scopul acestui studiu a fost să demonstrăm dacă terapia puls cu metilprednisolon (mPSL), administrat intravenos, ar putea avea beneficii clinice în tratamentul pacienților pediatrici diagnosticați cu complicații neurologice asociate SHU. Pe baza gravității cazurilor, pacienții au fost grupați în două categorii: pacienții cu SHU forma ușoară (creatinină serică $<1,5 \mathrm{mg} / \mathrm{dL}$ ), au fost comparați cu pacienții cu SHU forma severă (creatinină serică $>1,5 \mathrm{mg} / \mathrm{dL}$ și care asociază complicații neurologice). 16 din 89 de pacienți au prezentat SHU sever. Administrarea terapiei puls cu mPSL a dus la reducerea semnificativă a manifestărilor neurologice la un număr de 15 din 16 pacienți. Terapia cu mPSL nu a provocat efecte adverse semnificative. Analiza ROC a arătat performanța predictivă a parametrilor de laborator în grupul cu SHU forma severă (cu complicații neurologice), după administrarea mPSL. Valorile hemoglobinei au arătat o AUC (suprafața de sub curbă) de $0,8105, \mathrm{p}<0,0027$, iar creatinina serică a fost un predictor al SHU sever vs. forma ușoară. Creatinina serică a arătat o predicție bună pentru administrarea mPSL în grupul cu HUS sever (AUC 0,9453, intervalul de încredere 95\%, 0,8577 - 1,00, p < 0,0001). Datele noastre sugerează că utilizarea terapiei cu puls mPSL la copiii cu complicații neurologice în timpul fazei acute a SHU a fost asociată cu recuperarea evidentă a funcțiilor neurologice, hematologice și renale.

Keywords: haemolytic uremic syndrome, methylprednisolone, neurological complications, Escherichia coli enterohaemorrhagic, children

\section{Introduction}

The Haemolytic uremic syndrome (HUS) is a complex, multi-systemic disease, defined by the triad of micro-angiopathic haemolytic anaemia (haemoglobin $<10 \mathrm{~g} / \mathrm{dL}$ ), with schistocytes, thrombocytopenia (platelets $<150 * 10^{3} / \mathrm{mm}^{3}$ ), and impaired kidney function (serum creatinine 
FARMACIA, 2021, Vol. 69, 4

exceeding the standard age-related limit) [1]. HUS is a life-threatening disease, and the fatality rate in the acute phase is $3-5 \%$ [2].

Particularly in children, the most frequent cause of Diarrhoea-associated Haemolytic Uremic Syndrome (D+HUS) is the Shiga-toxin (Stx)-producing Escherichia coli (STEC). Stxs can be divided into two types (Stx1 and Stx2) and several subtypes, with Stx 2 usually leading to more severe symptoms $[3,4]$. Typically, STEC is acquired from contaminated food and drinks and cases appear sporadically or in the context of epidemics. The "typical" form is mediated by Shiga-like toxinproducing Escherichia coli (STEC-HUS) or, less commonly, by Shiga toxin-producing Shigella dysenteriae type 1 and Streptococcus pneumoniae [5].

HUS is one of the most common aetiologies for acute kidney injury and a significant cause of acquired chronic kidney disease in children [6]. In $90 \%$ of paediatric cases, the disease usually develops as a complication of the gastrointestinal EHEC infection [7]. An EHEC-HUS case was defined as a patient with clinical HUS and evidence (by immunological methods) of Stx toxins found in enriched stool culture. Among such extrarenal complications in children with EHEC-HUS, the most threatening involves CNS manifestations with an incidence estimated at $17-34 \%$ [8-14]. How exactly CNS damage occurs is still unknown, but it may be the result of pathogenetic mechanisms similar to those observed in the kidney, toxins binding to CNS endothelial cells and neurons, blood-brain barrier lesion and induction of various inflammatory mediators $[15,16]$. Thus, the brain oedema brought about by acute Shiga toxin- and cytokine-mediated vascular endothelial cell injury or higher vascular permeability may be the root cause of CNS complications associated with EHEC-HUS. CNS involvement in D+HUS is associated and usually manifests as irritability and seizures; however, in more severe cases, paresis, coma, and cerebral oedema may also occur. Such CNS manifestations may happen in approximately $10-50 \%$ of cases, and they are the main cause of death in children under 5 years of age $[5,6,17]$. Until recently, the treatment of HUS has been mainly supportive, consisting of fluid therapy, dialysis, plasmapheresis/plasma infusion and treatment of complications [18-20].

Although used for over 40 years in clinical practice as conventional high-dose intravenous mPSL pulse therapy, little is known generally about glucocorticoids mechanism of action and the frequency and severity of associated adverse effects [21-23]. mPSL availability to bind to the glucocorticoid and mineralocorticoid receptors is controlled by intracellular metabolism by $11 \beta$ -
Hydroxisteroid dehydrogenase, while cytochrome $\mathrm{P} 450$ is the most essential enzyme system acting in phase I metabolism [15]. Since the P-glycoprotein is also located in the liver and kidney, elimination of the metabolites occurs mainly by hepatic metabolism and renal excretion. A direct relation has been observed between the total mPSL clearance and the mPSL unbound fraction. Renal excretion of unchanged mPSL occurs approximately $11-24 \%$ after administration. An essential role in decisions on specific therapeutic regimens such as dosing and treatment duration lies with PK parameters (e.g., elimination half-life), and PD parameters (e.g., the concentration required for the half-maximal effect). These parameters' contribution to efficacy may be outlined through $\mathrm{PK} / \mathrm{PD}$ analysis, where endogenous cortisol and $\mathrm{T}$ helper cell counts may be used as biomarkers for mPSL effects [15].

Adverse effects and toxic impact of glucocorticoids depend on treatment duration and the dose used. Such events manifest as weight gain, hyperglycaemia, hypertension, dyslipidaemia, flaky skin, higher risk of fractures, and infections. Most foreseeable adverse reactions result from decreased pro-inflammatory genes and increased expression of anti-inflammatory and regulatory proteins [24]. Research into individual genetic factors is also needed to elucidate the patient-specific PK and PD profile, enabling customisation of glucocorticoid therapy and therefore improved patient outcomes [25-32].

This study has aimed to investigate the role of high dose intravenous mPSL pulse therapy in paediatric patients with neurological complications diagnosed with HUS and to determine whether steroids may be of clinical benefits for treating CNS complications during the acute phase of the disease. The research has been based on the premise that mPSL treatment administered intravenously in the acute phase of neurological complications in paediatric patients with HUS may improve the disease's course and reduce complications.

\section{Materials and Methods}

Study design

This is a retrospective study developed in the Nephrology Department of the "Maria SklodowskaCurie" Children's Hospital Bucharest, Romania. The study was conducted in accordance with the Declaration of Helsinki and the Good Clinical Practice guidelines. The study protocol was approved by the Ethics Committee from "Marie Sklodowska-Curie" Hospital, Bucharest, Romania.

Population

In this study, the electronic hospital records of 89 paediatric patients with Diarrhoea-associated HUS, 
who were admitted from January 2015 to December 2020, were analysed retrospectively. The clinical definitions for the two groups were applied as follow: severe-HUS: serum creatinine $\geq 1.5 \mathrm{mg} / \mathrm{dL}$ associated neurological symptoms, mild-HUS: serum creatinine $<1.5 \mathrm{mg} / \mathrm{dL}$ and absence of neurological symptoms. Neurological involvement was defined as encephalopathy, focal neurological deficit and/or seizure activity. No patients were excluded from this study.

Data collection

All the information on cases of HUS diagnosed in our hospital was obtained from electronic medical records. Written informed consent was obtained from the children's parents or legal guardians.

Laboratory methods

Biochemical indicators, including: glucose, urea, creatinine, total and direct bilirubin, uric acid, triglycerides, total cholesterol, HDL (high-density lipoprotein) and LDL (low-denstiy lipoprotein) cholesterol), enzymes (amylase, alkaline phosphatase (AP), alanine aminotransferase (ALT), aspartate aminotransferase (AST), lactate dehydrogenase (LDH) and lipase), electrolytes (sodium, potassium, chloride, magnesium), proteins (total protein, albumin), were obtained by an auto-analyser Roche Cobas 6000, Roche Diagnostics.

Regarding the microbiological criteria used in this study, the kit was CerTest (Biotec, Bioscience SL, Zaragoza, Spain) - EHEC Stx1 + Stx2, based on the principle of a qualitative immunochromatographic assay employing monoclonal antibodies for direct detection of Stx1 and Stx2 produced by STEC in stool samples. The manufacturer reported both sensitivity and specificity of $\sim 99 \%$ for the CerTest E. coli $\mathrm{O} 157+$ Stx1 + Stx2. A presumptive STECassociated HUS was inferred from a Stx1 and/or Stx2 PCR-positive stool culture whereas the recovery of the STEC strain confirmed the STEC infection. In addition, for 11 culture-negative patients the presumption of STEC infection was based on seropositivity for the E. coli $\mathrm{O} 157$ or $\mathrm{O} 26$ lipopolysaccharide.

Pulse therapy is defined as discontinuous intravenous administration of very high doses of corticosteroids over a short period. The aim of pulse mPSL therapy is to achieve faster response and stronger efficacy. For all patients with neurological complications, methylprednisolone $500 \mathrm{mg}$ a dose of $30 \mathrm{mg} / \mathrm{kg} /$ day for three consecutive days was intravenous administered under the supervision of the physician in the Intensive Care Unit (ICU) of the same clinic. To observe mPSL pulse efficiency in HUS paediatric patients with neurological complications, they were monitored as shown by laboratory test outcomes. For neurological evaluation after mPSL pulse therapy, physical examination and cerebral computer tomography was conducted. Brain CTs were performed using a GE BrightSpeed 8 Slice device 2008 provided with Volume Viewer 4.0 software.

Statistical analysis

Demographic and disease parameters were compared between the 2 groups (mild-HUS and severe-HUS) of subjects. Median with inter-quartile range was calculated and test and Wilcoxon test was used to compare medians.

Univariable and multivariable logistic regression were used to assess the role of adequate treatment of mPSL pulse therapy during HUS in predicting a favourable course. The sensitivity and specificity were calculated for the factor which was found to independently predict a frequently relapsing or steroid dependent course. ROC curve was also constructed to evaluate the performance of the predictive factor. All analyses were done by GraphPad Prism statistical software (GraphPad Software, 9.0.0 version, San Diego CA, USA) and significance was taken at a p-value of 0.05 .

\section{Results and Discussion}

A total of 89 patients with HUS were included in this study, with the number of girls slightly exceeding the number of boys included (52 girls $58.43 \%$ vs. 37 boys $-41.57 \%$ ), the median age being 12 months, (range: 6 - 72 months). The main demographic and clinical data of the two groups divided into disease severity, are presented in Table I.

Table I

Demographic and clinical characteristics of patients

\begin{tabular}{|c|c|c|}
\hline $\begin{array}{c}\text { Total } \\
\mathbf{N}=89\end{array}$ & $\begin{array}{c}\text { Mild HUS } \\
(\mathbf{N}=73)\end{array}$ & $\begin{array}{c}\text { Severe HUS } \\
\quad(\mathbf{N}=16)\end{array}$ \\
\hline \multicolumn{3}{|l|}{ Gender (\%) } \\
\hline Male*** & $42.5 \%$ & $37.5 \%$ \\
\hline Females*** & $57.5 \%$ & $62.5 \%$ \\
\hline Age groups -years & $\mathrm{N}(\%)$ & \\
\hline $0-1$ & $39(53.42 \%)$ & $9(56.25 \%)$ \\
\hline $2-4$ & $27(36.98 \%)$ & $5(31.25 \%)$ \\
\hline $5-9$ & $6(8.22 \%)$ & $2(12.5 \%)$ \\
\hline $10-14$ & $1(1.37 \%)$ & 0 \\
\hline \multicolumn{3}{|l|}{ Clinical data } \\
\hline Diarrhoea $* * *$ & $73(100 \%)$ & $16(100 \%)$ \\
\hline Bloody stool ** & $35(47.94 \%)$ & $14(87.5 \%)$ \\
\hline Pallor $* * *$ & $73(100 \%)$ & $16(100 \%)$ \\
\hline Oedema $* *$ & $12(16.44 \%)$ & $14(87.5 \%)$ \\
\hline Fever ** & $21(28.77 \%)$ & $12(75 \%)$ \\
\hline
\end{tabular}

The median time from admission was one day, (IQR: 0.0 - 1.4). Among 16 patients, neurological complications included seizures (43.75\%), alteration of consciousness (12.5\%), hyperexcitability (31.25\%), remitted strabismus (18.75\%), lethargy (12.5\%), convergent cranial nerve palsy (nerve -VI) $6.25 \%$, and hyperreactivity-associated drowsiness in $6.25 \%$. 
Serum urea and creatinine levels and LDH were increased in group with severe HUS, $(p \leq 0.05$, Wilcoxon signed rank test). $\mathrm{Hb}$ concentration were higher in group with mild HUS, $(\mathrm{p}<0.001)$. The maximum increase in serum creatinine and serum urea preceded the onset of neurological symptoms, whereas creatinine and serum urea levels decreased progressively over the days following mPSL pulse therapy administration (Figures 5 and 6). A statistical correlation was noted between the haematocrit and haemoglobin values on one hand and the onset of neurological symptoms, on the other hand. All the parameters are presented in Table II.

Table II

Laboratory parameters of patients with mild HUS and severe HUS, at admission

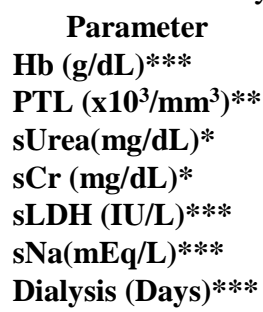

Mild HUS $(\mathbf{N}=\mathbf{7 3})$
$8.7(6.7-9.6)$
$89(55-107.5)$
$55(35.5-89)$
$2.15(1.025-3.625)$
$3.067(2.129-4.079)$
$132(120-132)$
$8(4-12.5)$

Severe HUS $(\mathbf{N}=\mathbf{1 6})$
$7.95(7.18-9.3)$
$95(64.3-123.3)$
$94(43.8-121)$
$3.85(2.275-4.357)$
$4.125(2.645-4.635)$
$122(102-122.5)$
$20(13-33)$

Data are presented as the median with the interquartile range (IQR 25-75\%). Creatinine serum (sCr), haemoglobin ( $\mathrm{Hb}$ ), urea serum (sUrea), PTL-platelet, serum lactate dehydrogenase (sLDH), serum Sodium (sNa). $\left.{ }^{*} \mathrm{p} \leq 0.05,{ }^{* *} \mathrm{p} \leq 0.01,{ }^{* * *} \mathrm{p} \leq 0.001\right)$.

In the total group, $71.91 \%$ required dialysis. Significantly more patients in the severe-HUS group needed dialysis than in the mild-HUS group (89\% vs. 67.9\%, $\mathrm{p}<0.001$ ). The most common was peritoneal dialysis (PD) $(88.7 \%)$ or haemodialysis (HD).

We found that patients in the severe-HUS group had longer hospital stays, lower platelet and haemoglobin counts, and higher serum creatinine and urea levels before administration of pulse therapy with methylprednisolone. This medication

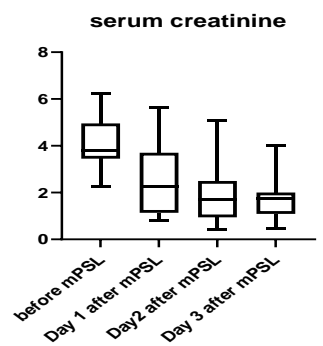

Figure 1. before and after mPSL administration
Serum creatinine levels

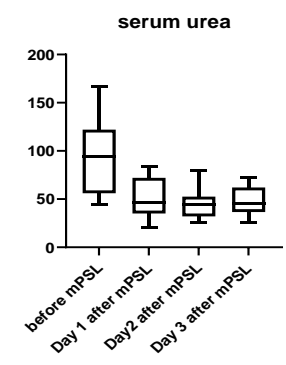

Figure 2.

Serum urea levels, before administration and after mPSL

Serum creatinine levels $(\mathrm{mg} / \mathrm{dL})$, in the group with severe-HUS, before mPSL administration, was significantly higher $(3.983, \pm 1.196)$, than after mPSL administration, day 3, $(1.729 \pm 0.9220), \mathrm{p} \leq$ 0.001 . There was statistically significance on serum urea levels, within administration of mPSL. Mean value before $\mathrm{mPSL}$ was $98.27 \pm 40.73 \mathrm{mg} / \mathrm{dL}$, and decreased to $47.33 \pm 15.31 \mathrm{mg} / \mathrm{dL}(\mathrm{p} \leq 0.001)$, after 3 days of mPSL administration. Haemoglobin level $(\mathrm{g} / \mathrm{dL})$, in group with severe-HUS, has been rising gradually, from $7.663 \pm 1.414$, before $\mathrm{mPSL}$, to $9.444 \pm 1.646(\mathrm{p}<0.001)$ after consecutively 3 days of mPSL administration. The function of platelets induces both haematological and renal remission especially if it is started early. As seen in figure 12 , serum creatinine and urea decreased during the three days of mPSL administration, while the platelets and haemoglobin levels (Figures 3 and 4) increased, and no significance adverse reaction have been observed. The characteristics of children according to mPSL response are shown below, in Figures 1-4.

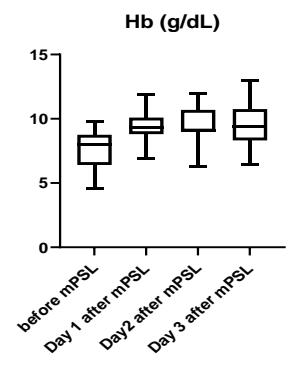

Figure 3.

Haemoglobin levels, before and after mPSL administration

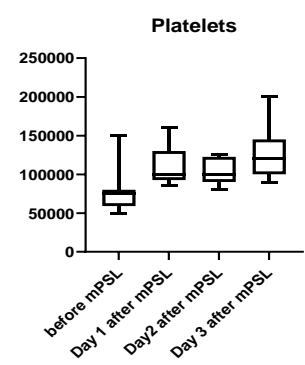

Figure 4.

Platelets levels before and after mPSL pulse therapy administratio significantly differs between mPSL administration. In the severe-HUS group, the platelets level was lower before $\mathrm{mPSL}$, mean value $79 \pm 33.3 \times 10^{3} / \mathrm{mm}^{3}$ than after 3 days of pulse therapy administration of mPSL $129.5 \pm 36.2 \times 10^{3} / \mathrm{mm}^{3}$, $(\mathrm{p}<0.05)$. Mean platelet count followed a tendency to recover by 7 10 days during hospitalization.

ROC curve was constructed to assess the predictive performance of mPSL treatment in the severe-HUS group. It was seen that administration of intravenous pulse therapy of mPSL was associated with laboratory parameters as predictors for steroids course (Figure 5 and Figure 6). 
FARMACIA, 2021, Vol. 69, 4

\section{A. ROC curve: $R O C$ of $\mathrm{Hb}(\mathrm{g} / \mathrm{dL})$}

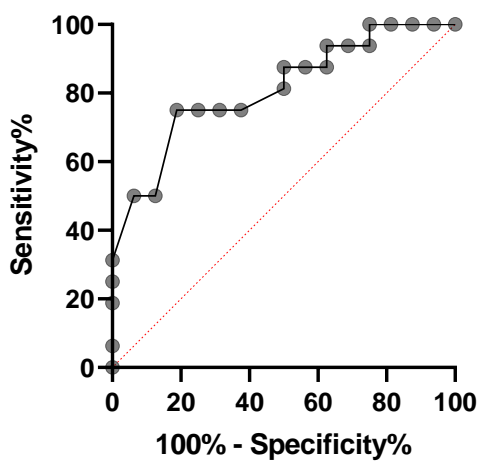

Area: 0.8105

Std. Error:0.07626

95\% confidence interval:0.6611 to 0.9600 $\mathrm{P}$ value 0.0027

\section{B. ROC curve: ROC of PLT}

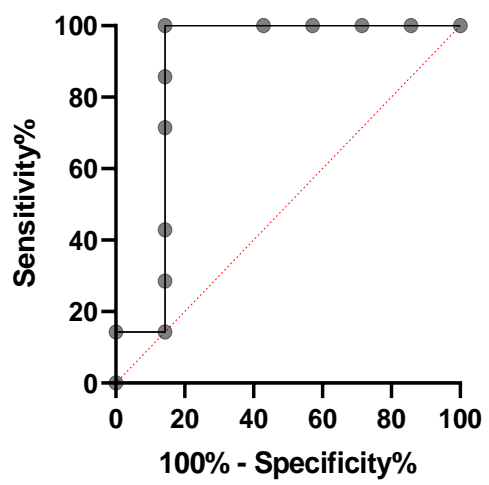

Area:0.8776

Std. Error:0.1163

95\% confidence interval:0.6497 to 1.000

$\mathrm{P}$ value 0.0181

Figure 5.

ROC curve of $\mathrm{Hb}$ and platelets in group with severe-HUS, after mPSL (A: Haemoglobin, B: Platelets)

ROC curve analysis was carried out to assess the performance of mPSL in the assessment of severeHUS group. Logistic regression analysis revealed an AUC of 0.8105 (Figure 5-A), with a 95\% confidence interval of $0.6611-0.9600$, for $\mathrm{Hb}$.

\section{ROC curve: ROC of serum creatinine}

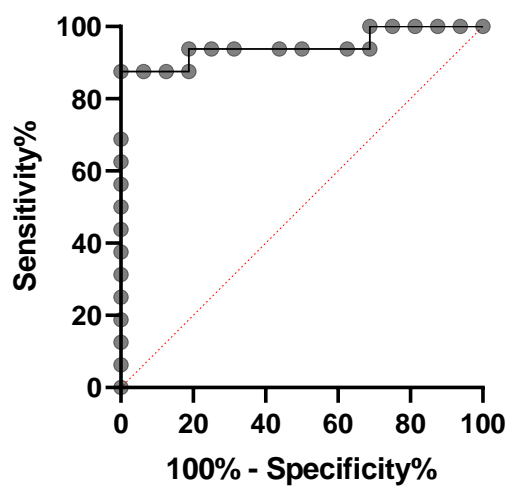

Area:0.9453

Std. Error:0.04469

95\% confidence interval:0.8577 to 1.000 $P$ value $<0.0001$
Among the patients with severe-HUS, figure 5-B shows significantly better hematological outcomes for PLT, p $<0.0181$ and AUC $=0.8776$, after mPSL administration.

\section{ROC curve: ROC of serum urea}

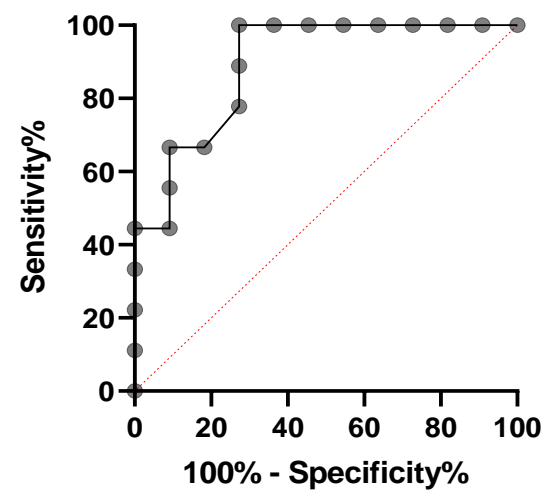

Area:0.8939

Std. Error:0.07080

95\% confidence interval:0.7552 to 1.000

$P$ value 0.0030

Figure 6.

ROC curves of serum creatinine and serum urea levels of the patients with severe-HUS, who underwent mPSL pulse therapy (C: Serum creatinine, D: Serum urea)

AUC of creatinine serum of $0.9453,(95 \%$ CI, 0.8577 - 1.000), and 0.8939 (95\% CI, 0.7552 - 1.000) respectively

This single center study explored the association between mPSL administration and disease activity in the group with severe-HUS. To analyse both groups of mild-HUS and severe-HUS, we defined kidney involvement in mild-HUS cases by a creatinine cut-off $<1.5 \mathrm{mg} / \mathrm{dL}$, and in the severeHUS group cut-off of serum creatinine was $>1.5 \mathrm{mg} / \mathrm{dL}$ and associated with neurological complications. The reported rate of neurological involvement in children with HUS was $17.98 \%$, based on seizures, encephalopathy, irritability or lethargy, or focal neurological deficit. Seizure $(43.75 \%)$ was the most common presentation of neurological involvement. Children in the severeHUS group had a significantly need for dialysis (median 20 vs. 8 days, $\mathrm{p}<0.0001$ ) and a longer length of hospital stay 33 (23 - 46) vs. 11 (14 - 20)], $\mathrm{p}<0.000$, reflecting the more severe course of illness in the severe-HUS group. CT in children with severe-HUS is focused on the changes which 
FARMACIA, 2021, Vol. 69, 4

show reversible lesions in children with good neurological recovery, and routine follow up imaging is not required unless abnormal neurological examination was found. Serum level of creatinine was the best predictor of a poor outcome, with $\mathrm{AUC}=0.9453$. The highest values for $\mathrm{LDH}$, serum creatinine and urea, occurred in patients with severeHUS. We showed that a dose of $30 \mathrm{mg} / \mathrm{kg} /$ day, for three consecutive days improve neurological manifestations and additionally promotes a protective, anti-inflammatory response. In 15 paediatric population of 16 , there was beneficial effects in imagistic, clinical and laboratory parameters after mPSL pulse therapy. The main causes of neurological complications are local microangiopathy, hypertension hyponatremia and local toxic effect of the bacterial toxin. In our study, hyponatremia, as the main metabolic cause of cerebral oedema, was present in severe-HUS. Brain CT was performed, which showed no pathological changes in 15 patients during hospitalization. Dynamically, 4 days from the onset of the first neurological manifestations, 1 patient presented deviation of the eyeballs to the left, horizontal nystagmus, low responds to verbal stimuli, and hypertension myoclonus. After mPSL administration, the cerebral CT scan was repeated, which revealed cerebral ischemia lesions in the occipital area, and had longterm neurologic sequelae. The cerebral CT evaluation showed only slight cerebral oedema in 3 patients (18.75\%), 1 patient $(6.25 \%)$ had minimal cerebral atrophy, whereas cerebral CT scans were routine for 11 children $(68.75 \%)$. Overall, 15 children of the 16 found with neurological complications had a remarkable response to high dose mPSL therapy and recovered within the first week.

Studies based on cohorts of children with HUS and CNS involvement before 2010 had a median mortality rate of $16.9 \%$ (IQR: $7.0-44.6 \%$ ) [13, 33]. More recent studies (cohorts after 2010), have better outcomes with lower mortality, $13.9 \%$ (IQR:12.5 - 22\%)] [34]. Over the past two decades, high-dose intravenous mPSL pulse therapy (an approach already used to treat several neurological syndromes) has been used in various studies in the field of HUS to avoid the development of side effects and maintain long-term efficacy [22, 35-38, 43]. In a previous study, a 14-year-old girl was successfully treated of STEC-HUS and acute encephalopathy with high-dose steroid pulse therapy (two courses of IV methylprednisolone $500 \mathrm{mg} /$ day for 3 days) in association with plasma exchange, obtaining full recovery [37]. Administered according to different regimens (dosage $30 \mathrm{mg} / \mathrm{kg} /$ day for three days), it has been shown to be successful in different disorders (absence seizures, infantile spasms, encephalopathies in general) [35, 39-45].
Our study provides an in-depth description of 16 patients with neurological complications of HUS infection among 89 children in total diagnosed with HUS at the "Maria Sklodowska Curie" Children's Emergency Hospital - Bucharest, Romania, between 2015 and 2020. To date, management is still supportive mainly, and while specific therapy for HUS extrarenal complications is missing, our therapeutic decision was to give high dose intravenous mPSL as the treatment of choice for such neurological complications. This decision was based on several factors, including clinical features of the neurological manifestations during HUS, particularly based on the severity of the attack as the most significant factor, laboratory parameters measured during HUS progression and evolution, neurological symptoms and CT findings such as the presence/absence of CNS site where the symptoms/signs were localised. Neurological symptoms such as seizures significantly improved during and after the administration of iv mPSL treatment as presented in the results of studies conducted in other centres [39-45].

A better understanding of the pathophysiology underlying STEC HUS in paediatric patients is essential if targeted therapy for this condition is to be established. Our study limitations result from its retrospective character and a small group of patients with neurological complications. However, the sample size is reasonably large to draw significant conclusions on a descriptive basis [40, 46].

\section{Conclusions}

Our study shows that intravenous mPSL pulse therapy was associated with decreased neurological clinical manifestations and measurable improvement in biological evidence. More extensive, consistent, and systematic study and prospective randomized clinical trials are needed to confirm and assess the safety of this therapy and further study the mid-term and long-term outcomes after discharge.

\section{Conflict of interest}

The authors declare no conflict of interest.

\section{References}

1. Loirat C, Frémeaux-Bacchi V, Atypical hemolytic uremic syndrome. Orphanet J Rare Dis., 2011; 6: 60: 1-30.

2. Wong CS, Mooney JC, Brandt JR, Staples AO, Jelacic S, Boster DR, Watkins SL, Tarr PI, Risk factors for the hemolytic uremic syndrome in children infected with Escherichia coli O157:H7: a multivariable analysis. Clin Infect Dis., 2012; 55(1): 33-41. 
FARMACIA, 2021, Vol. 69, 4

3. Colic E, Dieperink H, Titlestad K, Tepel M, Management of an acute outbreak of diarrhoeaassociated haemolytic uraemic syndrome with early plasma exchange in adults from southern Denmark: an observational study. Lancet, 2011; 378: 10891093.

4. Czock D, Keller F, Rasche FM, Häussler U, Pharmacokinetics and pharmacodynamics of systemically administered glucocorticoids. Clin Pharmacokinet., 2005; 44(1): 61-98.

5. Jenssen GR, Hovland E, Bjerre A, Bangstad HJ, Nygard K, Vold L, Incidence and aetiology of haemolytic-uremic syndrome in children in Norway, 1999-2008 - A retrospective study of hospital records to assess the sensitivity of surveillance. BMC Infect Dis., 2014; 14: 265: 1-9.

6. Igarashi T, Ito S, Sako M, Saitoh A, Hataya H, Mizuguchi M, Morishima T, Ohnishi K, Kawamura N, Kitayama H, Ashida AkAira, Kaname S, Taneichi H, Tang J, Ohnishi M, Study group for establishing guidelines for the diagnosis and therapy of hemolytic uremic syndrome. Guidelines for the management and investigation of hemolytic uremic syndrome. Clin Exp Nephrol., 2014; 18: 525-557.

7. Trachtman H, Austin C, Lewinski M, Stahl RAK, Renal and neurological involvement in typical Shiga toxin-associated HUS. Nat Rev Nephrol., 2012; 8: 658-669.

8. Bale JF Jr, Brasher C, Siegler RL, CNS manifestations of the hemolytic uremic syndrome. relationship to metabolic alterations and prognosis. Am J Dis Child., 1980; 134(9): 869-872.

9. Sheth KJ, Swick HM, Haworth N, Neurological involvement in hemolytic-uremic syndrome. Ann Neurol., 1986; 19(1):90-93.

10. Hahn JS, Havaens PL, Higgins JJ, O'Rourke PP, Estroff JA, Strand R, Neurological complications of hemolytic-uremic syndrome. J Child Neurol., 1989; 4(2): 108-113.

11. Siegler RL, Pavia AT, Christofferson RD, Milligan MK, A 20-year population-based study of postdiarrheal hemolytic uremic syndrome in Utah. Pediatrics, 1994; 94(1): 35-40.

12. Eriksson KJ, Boyd SG, Tasker RC, Acute neurology and neurophysiology of haemolyticuraemic syndrome. Arch Dis Child., 2001; 84(5): 434-435.

13. Gerber A, Karch H, Allerberger F, Verweyen HM, Zimmerhackl LB. Clinical course and the role of shiga toxin-producing Escherichia coli infection in the hemolytic-uremic syndrome in pediatric patients, 1997-2000, in Germany and Austria: a prospective study. J Infect Dis., 2002; 186(4): 493500.

14. Yamamoto T, Satomura K, Okada S. Ozono K, Risk factors for neurological complications in complete hemolytic uremic syndrome caused by Escherichia coli O157. Pediatrics Int., 2009; 51(2): 216-219.

15. Schijvens AM, Ter Heine R, de Wildt SN, Schreuder MF, Pharmacology and pharmacogenetics of prednisone and prednisolone in patients with nephrotic syndrome. Pediatric Nephrol., 2019; 34(3): 389-403.

16. Karpman D, Loos S, Tati R, Arvidsso I, Haemolytic uraemic syndrome. J Intern Med., 2017; 281: 123-148.

17. Kamioka I, Yoshiya K, Satomura K, Kaito H, Fujita T, Iijima $\mathrm{K}$, Nakanishi $\mathrm{K}$, Yoshikawa N, Nozu K, Matsuo M, Risk factors for developing severe clinical course in HUS patients: a national survey in Japan. Ped Int., 2008; 50: 441-446.

18. Matussek A, Einemo IM, Jogenfors A, Lofdahl S, Lofgren S, Shiga toxin-producing Escherichia coli in the diarrheal stool of Swedish children: evaluation of polymerase chain reaction screening and duration of Shiga toxin shedding. $J$ Pediatric Infect Dis Soc., 2016; 5: 147-151.

19. Nathanson S, Kwon T, Elmaleh $M$, Charbit $M$, Allain Launay E, Harambat J, Brun M, Ranchin B, Bandin F, Cloarec S, Bourdat-Michel G, Piètrement C, Champion G, Ulinski T, Deschênes G, Acute Neurological Involvement in Diarrhea-Associated Hemolytic Uremic Syndrome. Clin J Am Soc Nephrol., 2010; 5: 1218-1228.

20. Noris M, Remuzzi G, Hemolytic Uremic Syndrome. J Am Soc Nephrol., 2005; 16: 10351050.

21. Pera MC, Randazzo G, Masnada S, Donetti Dontin $\mathrm{S}$, De Giorgis V, Balottin U, Veggiotti $\mathrm{P}$, Intravenous methylprednisolone pulse therapy for children with epileptic encephalopathy. Funct Neurol., 2015; 30(3): 173-179.

22. Perez N, Spizzirri F, Rahman R, Suarez A, Larrubia C, Lasarte P, Steroids in the hemolytic uremic syndrome. Pediatr Nephrol., 1998; 12(2): 101-104.

23. Peron E, Zaharia A, Zota LC, Severi E, Mårdh O, Usein C, Bălgrădean M, Espinosa L, Jansa J, Scavia G, Rafila A, Serban A, Pistol A. Early findings in outbreak of hemolytic uremic syndrome among young children caused by Shiga toxinproducing Escherichia coli. Romania, January to February 2016, www.eurosurveillance.org.

24. Magee MH, Blum RA, Lates CD, Jusko WJ, Prednisolone Pharmacokinetics and Pharmacodynamics in Relation to Sex and Race. J Clin Pharmacol., 2001; 41(11): 1180-1194.

25. Picard C, Burtey S, Bornet C, Curti C, Montana M, Vanelle $\mathrm{P}$, Pathophysiology and treatment of typical and atypical haemolytic uremic syndrome. Pathologie Biologie, 2015; 63: 136-143.

26. Papacocea T, Popa E, Turliuc D, Papacocea R, The usefulness of dexamethasone in the treatment of chronic subdural hematomas. Farmacia, 2019; 67(1): 140-145.

27. De Rauw K, Buyl R, Jacquinet S, Pierard D, Risk determinants for the development of typical haemolytic uremic syndrome in Belgium and proposition of a new virulence typing algorithm for Shiga toxin-producing Escherichia coli. Epidemiol Infect., 2018; 5:1-5.

28. Handra C, Coman OA, Coman L, Enache T, Stoleru S, Sorescu AM, Ghiță I, Fulga I, The connection between different neurotransmitters involved in cognitive processes. Farmacia, 2019; 67(2): 193-201. 
29. Takanashi J-i, Taneichi H, Misaki T Yahata Y, Okumura A, Ishida Y-i, Miyawaki T, Okabe No, Sata T, Mizuguchi M, Clinical and radiologic features of encephalopathy during $2011 \mathrm{E}$. coli O111 outbreak in Japan. Neurology, 2014; 82: $564-$ 572.

30. Riaz MK, Potential drug-drug interactions and strategies for their detection and prevention. Farmacia, 2019; 67(4): 572-579.

31. Balgradean M, Ceausu M, Cinteza E, Filipoiu F, Death caused by hemolytic-uremic syndrome. Case series. RJML, 2013; 21(3): 185-192.

32. Tarr PI, Gordon CA, Chandler WL, Shiga-toxinproducing Escherichia coli and haemolytic uraemic syndrome. Lancet, 2005; 365: 1073-1086.

33. Matthies J, Hünseler C, Ehren R, Volland R, Körber F, Hoppe B, Weber LT, Habbig S, Extrarenal manifestations in Shiga toxin-associated haemolytic uremic syndrome. Klin Paediatr., 2016; 228: 181-188.

34. Brown CC, Garcia X, Bhakta RT, Sanders E, Prodhan P, Severe Acute Neurologic Involvement in Children With Hemolytic-Uremic Syndrome. Pediatrics, 2021; 147(3): e2020013631.

35. Yoshimitsu M, Hayashi N, Kaneko Y, Doyama H, An adult case of combined encephalopathy and hemolytic uremic syndrome caused by Escherichia coli O157. Nihon Shokakibyo Gakkai Zasshi, 2011; 108(1): 74-9.

36. Matsumoto T, Fan X, Ishikawa E, Ito M, Amano K, Toyoda H, Komada Y, Ohishi K, Katayama N, Yoshida Y, Matsumoto M, Fujimura Y, Ikejiri M, Wada H, Miyata T, Analysis of patients with atypical hemolytic uremic syndrome treated at the Mie University Hospital: concentration of C3 p.I1157T mutation. Int J Hematol., 2014; 100(5): 437-442.

37. Yada N, Fujioka M, Bennett CL, Inoki K, Miki T, Watanabe A, Yoshida T, Hayakawa M, Matsumoto M, Fujimura Y, STEC:O111-HUS complicated by acute encephalopathy in a young girl was successfully treated with a set of hemodiafiltration, steroid pulse, and soluble thrombomodulin under plasma exchange. Clin Case Rep., 2015; 3(4): 208212.

38. Akimoto T, Ito C, Kotoda A, Challenges of caring for an advanced chronic kidney disease patient with severe thrombocytopenia. Clin Med Insights Case Rep., 2013; 6: 171-175.

39. Ardissino G, Tel F, Possenti I, Testa S, Consonni D, Paglialonga F, Salardi S, Borsa-Ghiringhelli N, Salice P, Tedeschi S, Castorina P, Colombo RM, Arghittu M, Daprai L, Monzani A, Tozzoli R, Brigotti M, Torresani E, Early volume expansion and outcomes of hemolytic uremic syndrome. Pediatrics, 2016; 137: 1-9.

40. Siegler RL, The hemolytic uremic syndrome. Pediatr Clin North Am., 1995; 42(6): 1505-1529.

41. Saini A, Emke AR, Silva MC, Perlman SJ, Response to eculizumab in Escherichia coli O157: H7-induced hemolytic uremic syndrome with severe neurological manifestations. Clinical Pediatrics, 2015; 54: 387-389.

42. Schlieper A, Orrbine E, Wells GA, Clulow M, McLaine PN, Rowe PC, Neuropsychological sequelae of haemolytic uraemic syndrome. Investigators of the HUS Cognitive Study. Arch Dis Child., 1999; 80(3): 214-220.

43. Hosaka T, Nakamagoe K, Tamaoka A. Hemolytic Uremic Syndrome-associated Encephalopathy Successfully Treated with Corticosteroids. Internal Medicine, 2017; 56(21): 2937-2941.

44. Ardissino G, Dacco V, Testa S, Civitillo CF, Hemoconcentration: a major risk factor for neurological involvement in hemolytic uremic syndrome. Pediatric Nephrol., 2014; 30(2): 345352.

45. Balgradean M, Croitoru A, Leibovitz E, An outbreak of hemolytic uremic syndrome in southern Romania during 2015-2016, Epidemiologic, clinical, laboratory, microbiologic, therapeutic and outcome characteristics. Pediatr Neonatol., 2019; 60(1): 87-94.

46. Sheerin NS, Glover E, Haemolytic uremic syndrome: diagnosis and management, https://f1000research.com. 